\author{
Tomasz KLEIBER ${ }^{1 *}$, Włodzimierz KRZESIŃSKI ${ }^{2}$, Katarzyna PRZYGOCKA-CYNA ${ }^{3}$ \\ and Tomasz SPIŻEWSKI ${ }^{2}$
}

\title{
ALLEVIATION EFFECT OF SELENIUM ON MANGANESE STRESS OF PLANTS
}

\author{
ŁAGODZĄCY WPŁYW SELENU NA STRES MANGANOWY ROŚLIN
}

\begin{abstract}
Mn}$, as $\mathrm{Fe}, \mathrm{Zn}, \mathrm{Cu}$ and $\mathrm{Ni}$ is a heavy metal and also a necessary element all the living organisms. Excessive Mn nutrition causes a strong oxidative stress. The aim of the studies was to determination the effect of Se treatment (as sodium selenite $\mathrm{Na}_{2} \mathrm{O}_{4} \mathrm{Se}_{3}$ ) to alleviate the Mn stress of plants. Because of its sensitivity to oxidative stress induced by excessive concentrations of Mn a model plant was lettuce (Lactuca sativa L. 'Sunny'). The studies were conducted in a controlled environment growth room in stable climate conditions: $16 \mathrm{~h}$ photoperiod; temperature light/dark $18.0 \pm 0.5^{\circ} \mathrm{C} / 16.0 \pm 0.5^{\circ} \mathrm{C}$; relative humidity $70-80 \%$; quantum flux density $195-205 \mu \mathrm{mol} \mathrm{m} \mathrm{m}^{-2} \mathrm{~s}^{-1}$. Plants were grown hydroponically in nutrient solution characterized by excessive Mn content $\left(19.2 \mathrm{mg} \mathrm{dm}^{-3}\right)$ and different contents of Se (control; $\left.0.77,1.05,1.33 \mathrm{mg} \mathrm{dm}^{-3}\right)$. In all the combination were also tested different foliar sprays (distilled water and a $0.005 \%$ Se solution). Plants grown under conditions described above take up and transported Se from nutrient solutions into their leaves with a significant reduction of Mn concentration and changes in the plant nutrient status. With the increase in the concentrations of Se clearly narrowed quantitative relations in the leaves between this element and micro-metallic. Increasing Se levels in nutrient solution has a positive influence on the growth of plants, but Se foliar treatment generally decreases plant yield. The study shown that Se application may lead to alleviation of Mn stress of plants, with simultaneous reduce in $\mathrm{Mn}$ concentration in leaves - which may be of practical importance also in the cultivation of more economically important species.
\end{abstract}

Keywords: Mn toxicity, selenium, macroelements, microelements, hydroponic, lettuce

\section{Introduction}

Manganese (Mn) is an essential micronutrient to all the living organisms [1-3]. Excessive Mn uptake is a disadvantage and may cause physiological disorders. In case of plants it may significantly reduce biomass production, photosynthesis and caused biochemical disorders [4]. An important factor which influences the quality of plants is their nutrition, especially the quality of water used in plant watering. Generally most of the

\footnotetext{
${ }^{1}$ Department of Plants Nutrition, Poznań University of Life Sciences, ul. Zgorzelecka 4, 60-198 Poznań, Poland, phone +486184663 12, fax +486184663 05, email: tkleiber@up.poznan.pl

${ }^{2}$ Department of Vegetable Crops, Poznań University of Life Sciences, ul. Dąbrowskiego 159, 60-594 Poznań, Poland, phone +48 6184879 66, fax +48 6184879 66, email: brassica@up.poznan.pl; spizewsk@up.poznan.pl

${ }^{3}$ Department of Agricultural Chemistry and Environmental Biogeochemistry, Poznań University of Life Sciences, ul. Wojska Polskiego 71F, Poznań, Poland, phone +48 61487 782, fax +48 618487787

*Corresponding author: tkleiber@up.poznan.pl
} 
water sources contain lower concentrations of $\mathrm{Mn}\left(<1 \mathrm{mg} \mathrm{dm}^{-3}\right)$. However also in other countries sometimes water may contain higher Mn concentration, for example in Scotland it was determined the concentration of $\mathrm{Mn}$ in drinking water up to $1.9 \mathrm{mg} \mathrm{dm}^{-3}$ what is clearly exceeding the limit of $0.05 \mathrm{mg} \mathrm{dm}^{-3}$ [5]. Meanwhile in Poland in case of water used for drip irrigation and fertigation of horticultural was determined more than $4.0 \mathrm{mg} \mathrm{dm}^{-3}$ which is a concentration about 10-times higher than optimal for plants growing [6-8]. Excessive (without visual symptoms on plants) or toxic (with present visual symptoms of necrosis) contents of $\mathrm{Mn}$ in water/nutrient medium cause a significant accumulation of this nutrient in different edible parts (fruits and leaves) of vegetable species [7, 8]. European Commission Regulation No. 420/2011 of 29 April 2011 [9] sets maximum levels of $\mathrm{Hg}, \mathrm{Cd}$ and $\mathrm{Pb}$ in foodstuffs - but not for $\mathrm{Mn}$. An adequate intake $(A I)$ of $\mathrm{Mn}$ specified by the National Academies' Institute of Medicine is varing from $1.8 \mathrm{mg}$ (women) to $2.3 \mathrm{mg}$ (men) per day [1]. $11 \mathrm{mg} \mathrm{Mn} \mathrm{day}{ }^{-1}$ is a Tolerable Upper Intake Level (UL) of which was set for adults based on a no-observed-adverse-effect level for Western diets. It is known that heavy metals (including $\mathrm{Mn}$ ) constitute a consumer health hazard, due to their accumulation in vegetables and organisms $[10,11]$. Trace elements may accumulate in the some vitals like: liver, kidneys, myocardium [12] or brain [2,13] and their effects can be seen after several months, and even years [14]. The mechanism of Mn neurotoxicity is only little known [2].

An element which significantly alleviates oxidative stress of plants induced by excessive Mn nutrition is silicon ( $\mathrm{Si}$ ) $[15,16]$, but reports on the influence of $\mathrm{Si}$ on the concentration of $\mathrm{Mn}$ in edible parts of vegetables are inconclusive. Another element which may also alleviate metal stress is selenium (Se) which may also limit the heavy metals toxic effects [17-19]. In previous studies, a positive effect of $\mathrm{Se}$ was found on the $\mathrm{Pb}, \mathrm{Cd}$ and $\mathrm{Al}$ concentrations in tissues of different plant species [20-25]. At the same time many scientists focus on bio-fortification of vegetables with Se [26-28]. A low Se intake in the human body may increase the risk of cardiovascular diseases (CVD), cancer and other diseases, caused by free radicals [29, 30].

Because of its sensitivity to oxidative stress induced by excessive concentrations of $\mathrm{Mn}$ a model plant in our studies was a lettuce [7]. The aim of the conducted study was to determine the allevation effect of Se nutrition on plant yield and the concentrations of $\mathrm{Mn}$, $\mathrm{Se}$, and also other macro- and microelements in leaves of lettuce grown under strong $\mathrm{Mn}$ stress.

\section{Materials and method}

Experimental design. The studies were conducted in a chamber room located at the area of Experimental Station of the Departments of the Faculty of Horticulture and Landscape Architecture, the Poznan University of Life Sciences (Poland). The aim was to determine the effect of Se nutrition on chemical composition (especially $\mathrm{Se}$ and $\mathrm{Mn}$ concentrations) of leaves and on yield of lettuce (cv. 'Sunny') grown under strong Mn-stress. The experiments were conducted in a 2-factorial design with the factors: A - Se concentration in the nutrient solution (control+3 Se levels), B - foliar spraying (B1 - distilled $\mathrm{H}_{2} \mathrm{O}$; B2 - Se solution). The experiments were established in the systematic design in 4 replications.

The following stable climate conditions were maintained during the experiment: $16 \mathrm{~h}$ of photoperiod; temperature day/night $18 \pm 0.5^{\circ} \mathrm{C} / 16 \pm 0.5^{\circ} \mathrm{C}$; relative humidity (70-80\%); quantum flux density 195 to $205 \mu \mathrm{mol} \mathrm{m} \mathrm{m}^{-2} \mathrm{~s}^{-1}$. The quantum flux density was measured 
with the SunScan Canopy Analysis System (SS1, Delta-T Devices Ltd., Cambridge, England). The light source were high pressure sodium lamps.

Plant nutrition. Details of schedule of seedling preparation was shown earlier [7]. Plants were grown in hydroponically in rockwool blocks $(10 \times 10 \times 10 \mathrm{~cm})$ with recirculation of nutrient solution. A standard nutrient solution for lettuce was used (in $\mathrm{mg}$ $\mathrm{dm}^{-3}$ ): N-NH 4 10.0; N-NO ${ }_{3} 150.0 ; \mathrm{P}_{-} \mathrm{PO}_{4}$ 50.0; K 150.0; Ca 150.0; Mg 50.0; Fe 3.00; Mn 19.2; Zn 0.44; Cu 0.03; B 0.01; pH 5.50; EC $1.8 \mathrm{mS} \mathrm{cm}^{-1}$. Se was added to the nutrient solution at the following levels (in $\mathrm{mg} \mathrm{dm}^{-3}$ ): control, 0.77, 1.05, 1.33 (described as Se-I, Se-II and Se-III). Within each nutrient medium combination Se foliar spraying was applied $\left(10 \mathrm{~cm}^{3}\right.$ of $0.005 \%$ solution $\cdot$ plant $\left.^{-1}\right)$. The Se source was sodium selenate purum p.a. $\left(\mathrm{Na}_{2} \mathrm{O}_{4} \mathrm{Se}_{3}\right.$; Sigma-Aldrich). Plants were sprayed one time per cycle, 7 days after the start of the experiment. The control plants were cultivated without Se nutrition with distilled water spraying.

Chemical analysis. From every plant in each studied combination the leaves were collected, which were dried to constant weight and then ground. In order to assay the total forms of macroelements and $\mathrm{Na}$ the plant material was mineralized in concentrated $\mathrm{H}_{2} \mathrm{SO}_{4}$, while for analyses of microelements $(\mathrm{Fe}, \mathrm{Mn}, \mathrm{Zn}$ and $\mathrm{Cu})$ - in a mixture of $\mathrm{HNO}_{3}$ and $\mathrm{HClO}_{4}(3: 1, \mathrm{v} / \mathrm{v})$ [31, modified]. After mineralization the following determinations were performed: N-total using the distillation method according to Kjeldahl in a Parnas Wagner apparatus; P - colorimetrically with ammonia molybdate; $\mathrm{K}, \mathrm{Ca}, \mathrm{Mg}, \mathrm{Na}, \mathrm{Fe}, \mathrm{Mn}, \mathrm{Zn}, \mathrm{Cu}$ using flame atomic absorption spectroscopy (on a Carl Zeiss Jena apparatus). Se concentrations in the plant material were determined by hydride generation (HG-AAS). The method is based on the separation of $\mathrm{Se}$ in the form of $\mathrm{H}_{2} \mathrm{Se}$ from the sample matrix.

Statistical analysis. The data were analysed using STATISTICA (StatSoft Inc., Tulsa, OK, USA). The results were analysed by factorial ANOVA with Se content in nutrient solution and foliar sprays as fixed factors. Duncan's test was employed to analyze differences between measured parameters. There were also calculated the simple correlation coefficients between Se nutrition and nutrient concentration in leaves and plant yield.

\section{Results and discussion}

Plant yield. Se applied in nutrient medium directly to the root-zone influenced plant yield - the highest yield was obtained at the application of Se-III (Table 1). Generally (except for Se-II) Se foliar application decreased plant performance. Mean yield of plants sprayed with distilled water was higher than for Se-sprayed.

Chemical composition of plants. Se nutrition significantly modified the chemical composition of leaves (Tables 1 and 2). Concentrations of Mn under Se spraying varied but at the Se-III dose applied in nutrient solution a significant reduction was recorded in $\mathrm{Mn}$ concentration (reduction by about $36 \%$ comparing with the control). The plant response to Se spraying was varied. The Se concentration in leaves increased with an increase in Se concentration in nutrient solution. The highest Se concentration was found for Se-II with simultaneous Se spraying (3.71 $\left.\mathrm{mg} \mathrm{Se} \mathrm{kg}{ }^{-1} \mathrm{DM}\right)$, but the lowest for the control (distilled $\mathrm{H}_{2} \mathrm{O}$ sprayed). The Na concentration in leaves decreased under Se treatment to nutrient medium, although the effect of Se spraying was varied (for mean caused increasing of $\mathrm{Na}$ concentration). Se applied to the root zone (at Se-I, Se-III) significant decreased in the N concentration below the level of control. The P concentration in leaves for Se-I was higher, 
while for Se-II and Se-III was lower comparing with the control. The effect of Se-spraying on $\mathrm{N}$ and $\mathrm{P}$ concentrations was varied. Concentration of $\mathrm{K}$ in leaves was stable (except for Se-III), for which a significant decreased.

Se application - both via the root zone and foliar spraying - caused a significant $\mathrm{Ca}$ reduction. Concentrations of $\mathrm{Mg}$ varied (lower for Se-I and Se-III, while higher for Se-II). The mean $\mathrm{Mg}$ concentration under Se spraying was lower than in the control sprayed by distilled water. The Fe status was stable - except for Se-II, for which it was significantly higher (for the combination with distilled $\mathrm{H}_{2} \mathrm{O}$ spraying). Se application to the root zone significantly decreased the $\mathrm{Zn}$ concentration in leaves, but reaction on Se foliar spraying was varied. Se changed the $\mathrm{Cu}$ status of leaves but the changes were multi-directional.

Table 1

The effect of Se on yielding of plants $\left(\mathrm{g} \mathrm{head}^{-1}\right)$ and concentration of: Se and metallic microelements (express as $\mathrm{mg} \mathrm{kg}^{-1}$ of dry matter) in leaves of lettuce grown under Mn-stress

\begin{tabular}{|c|c|c|c|c|c|}
\hline \multirow{2}{*}{ Plant spraying } & \multicolumn{5}{|c|}{ Se level in nutrient solution } \\
\hline & Control & 0.77 & $\mathbf{1 . 0 5}$ & 1.33 & Mean \\
\hline \multicolumn{6}{|c|}{ Yielding of plants } \\
\hline Distilled water & $304.67 \mathrm{c}$ & $293.00 \mathrm{bc}$ & $267.00 \mathrm{ab}$ & $351.00 \mathrm{~d}$ & $303.92 \mathrm{~B}$ \\
\hline Se solution & $245.67 \mathrm{a}$ & $256.33 \mathrm{a}$ & $277.67 \mathrm{abc}$ & $299.67 \mathrm{bc}$ & $269.83 \mathrm{~A}$ \\
\hline Mean & $275.17 \mathrm{~A}$ & $274.67 \mathrm{~A}$ & $272.34 \mathrm{~A}$ & $325.33 \mathrm{~B}$ & \\
\hline \multicolumn{6}{|c|}{ Se } \\
\hline Distilled water & $2.64 \mathrm{a}$ & $2.93 \mathrm{~b}$ & $3.43 \mathrm{~d}$ & $3.35 \mathrm{~d}$ & $3.09 \mathrm{~A}$ \\
\hline Se solution & $2.83 \mathrm{~b}$ & $3.12 \mathrm{c}$ & $3.71 \mathrm{e}$ & $2.97 \mathrm{~b}$ & $3.16 \mathrm{~A}$ \\
\hline Mean & $2.74 \mathrm{~A}$ & $3.03 \mathrm{~B}$ & $3.57 \mathrm{D}$ & $3.16 \mathrm{C}$ & \\
\hline \multicolumn{6}{|c|}{ Mn } \\
\hline Distilled water & $639.45 \mathrm{~cd}$ & $662.35 \mathrm{~cd}$ & $736.50 \mathrm{e}$ & $468.25 \mathrm{a}$ & $626.64 \mathrm{~A}$ \\
\hline Se solution & $731.85 \mathrm{e}$ & $617.95 \mathrm{c}$ & $683.10 \mathrm{~d}$ & $566.30 \mathrm{~b}$ & $649.80 \mathrm{~B}$ \\
\hline Mean & $685.65 \mathrm{C}$ & $640.15 \mathrm{~B}$ & $709.80 \mathrm{C}$ & $517.27 \mathrm{~A}$ & \\
\hline \multicolumn{6}{|c|}{$\mathrm{Fe}$} \\
\hline Distilled water & $118.30 \mathrm{a}$ & $109.55 \mathrm{a}$ & $180.65 \mathrm{~b}$ & $116.05 \mathrm{a}$ & $131.14 \mathrm{~A}$ \\
\hline Se solution & $128.30 \mathrm{a}$ & $115.70 \mathrm{a}$ & $111.50 \mathrm{a}$ & $117.90 \mathrm{a}$ & $118.35 \mathrm{~A}$ \\
\hline Mean & $123.30 \mathrm{~A}$ & $112.63 \mathrm{~A}$ & $146.08 \mathrm{~B}$ & $116.98 \mathrm{~A}$ & \\
\hline \multicolumn{6}{|c|}{$\mathbf{Z n}$} \\
\hline Distilled water & $21.20 \mathrm{~b}-\mathrm{d}$ & $23.47 \mathrm{~cd}$ & $17.06 \mathrm{ab}$ & $15.58 \mathrm{a}$ & $19.32 \mathrm{~A}$ \\
\hline Se solution & $25.23 \mathrm{~d}$ & $20.22 \mathrm{a}-\mathrm{c}$ & $21.14 \mathrm{~b}-\mathrm{d}$ & $17.53 \mathrm{ab}$ & $21.03 \mathrm{~A}$ \\
\hline Mean & $23.22 \mathrm{C}$ & $21.84 \mathrm{BC}$ & $19.10 \mathrm{AB}$ & $16.55 \mathrm{~A}$ & \\
\hline \multicolumn{6}{|c|}{$\mathrm{Cu}$} \\
\hline Distilled water & $6.52 \mathrm{bc}$ & $7.87 \mathrm{de}$ & $8.74 \mathrm{e}$ & $5.52 \mathrm{ab}$ & $7.16 \mathrm{~A}$ \\
\hline Se solution & $7.94 \mathrm{de}$ & $5.27 \mathrm{a}$ & $7.13 \mathrm{~cd}$ & $8.20 \mathrm{de}$ & $7.13 \mathrm{~A}$ \\
\hline Mean & $7.23 \mathrm{AB}$ & $6.57 \mathrm{~A}$ & $7.93 \mathrm{~B}$ & $6.86 \mathrm{~A}$ & \\
\hline
\end{tabular}

Key for Tables 1-2: separately for rows and columns, means marked with the same capital letters do not differ significantly at $p<0.05$; within rows and columns, means marked with the same small letters do not differ significantly at $p=0.05$

A statistically significant negative linear correlation was found between Se content in the nutrient medium and $\mathrm{P}, \mathrm{K}, \mathrm{Ca}, \mathrm{Mg}, \mathrm{Na}, \mathrm{Mn}$ and $\mathrm{Zn}$ concentrations in leaves, while in the case of Se concentration in leaves and plant yield the correlation with $\mathrm{P}, \mathrm{K}, \mathrm{Ca}, \mathrm{Mg}, \mathrm{Na}$, $\mathrm{Mn}$ and $\mathrm{Zn}$ was significant and positive (Table 3). In the case of Se spraying significant and negative linear correlation coefficients were found only for $\mathrm{Ca}$ and $\mathrm{Mg}$ in leaves, as well as plants yield. Moreover, significant correlations were observed for a number of other parameters studied. 
Table 2

The effect of Se on macroelement and sodium concentration (express as \% of dry matter) in leaves of lettuce grown under Mn-stress

\begin{tabular}{|c|c|c|c|c|c|}
\hline \multirow{2}{*}{ Plant spraying } & \multicolumn{5}{|c|}{ Se level in nutrient solution } \\
\hline & Control & 0.77 & 1.05 & 1.33 & Mean \\
\hline \multicolumn{6}{|c|}{$\mathbf{N}$} \\
\hline Distilled water & $3.96 \mathrm{ef}$ & $3.54 \mathrm{~b}$ & $3.89 \mathrm{de}$ & $3.40 \mathrm{a}$ & $3.69 \mathrm{~A}$ \\
\hline Se solution & $3.61 \mathrm{bc}$ & $3.82 \mathrm{~d}$ & $3.68 \mathrm{c}$ & $4.03 \mathrm{f}$ & $3.78 \mathrm{~B}$ \\
\hline Mean & $3.78 \mathrm{~B}$ & $3.68 \mathrm{~A}$ & $3.78 \mathrm{~B}$ & $3.71 \mathrm{AB}$ & \\
\hline \multicolumn{6}{|c|}{$\mathbf{P}$} \\
\hline Distilled water & $0.99 \mathrm{c}$ & $1.07 \mathrm{f}$ & $0.93 \mathrm{~b}$ & $0.94 \mathrm{~b}$ & $0.98 \mathrm{~A}$ \\
\hline Se solution & $1.05 \mathrm{e}$ & $0.99 \mathrm{c}$ & $0.85 \mathrm{a}$ & $1.04 \mathrm{~d}$ & $0.98 \mathrm{~A}$ \\
\hline Mean & $1.02 \mathrm{C}$ & $1.03 \mathrm{D}$ & $0.89 \mathrm{~A}$ & $0.99 \mathrm{~B}$ & \\
\hline \multicolumn{6}{|c|}{$\mathbf{K}$} \\
\hline Distilled water & $6.51 \mathrm{~b}$ & $6.40 \mathrm{~b}$ & $6.39 \mathrm{~b}$ & $5.79 \mathrm{a}$ & $6.27 \mathrm{~A}$ \\
\hline Se solution & $6.57 \mathrm{~b}$ & $6.35 \mathrm{~b}$ & $6.53 \mathrm{~b}$ & $5.92 \mathrm{a}$ & $6.34 \mathrm{~A}$ \\
\hline Mean & $6.54 \mathrm{~B}$ & $6.37 \mathrm{~B}$ & $6.46 \mathrm{~B}$ & $5.86 \mathrm{~A}$ & \\
\hline \multicolumn{6}{|c|}{$\mathbf{C a}$} \\
\hline Distilled water & $1.85 \mathrm{e}$ & $1.70 \mathrm{~d}$ & $1.74 \mathrm{~d}$ & $1.49 \mathrm{bc}$ & $1.70 \mathrm{~B}$ \\
\hline Se solution & $1.53 \mathrm{c}$ & $1.39 \mathrm{a}$ & $1.46 \mathrm{a}-\mathrm{c}$ & $1.42 \mathrm{ab}$ & $1.45 \mathrm{~A}$ \\
\hline Mean & $1.69 \mathrm{D}$ & $1.55 \mathrm{~B}$ & $1.60 \mathrm{C}$ & $1.46 \mathrm{~A}$ & \\
\hline \multicolumn{6}{|c|}{ Mg } \\
\hline Distilled water & $0.86 \mathrm{c}$ & $0.88 \mathrm{c}$ & $0.99 \mathrm{~d}$ & $0.82 \mathrm{~b}$ & $0.89 \mathrm{~B}$ \\
\hline Se solution & $0.88 \mathrm{c}$ & $0.75 \mathrm{a}$ & $0.86 \mathrm{c}$ & $0.85 \mathrm{c}$ & $0.83 \mathrm{~A}$ \\
\hline Mean & $0.87 \mathrm{C}$ & $0.81 \mathrm{~A}$ & $0.92 \mathrm{D}$ & $0.84 \mathrm{~B}$ & \\
\hline \multicolumn{6}{|c|}{$\mathbf{N a}$} \\
\hline Distilled water & $0.056 \mathrm{~b}$ & $0.056 \mathrm{~b}$ & $0.061 \mathrm{c}$ & $0.055 \mathrm{~b}$ & $0.057 \mathrm{~A}$ \\
\hline Se solution & $0.068 \mathrm{~d}$ & $0.062 \mathrm{c}$ & $0.061 \mathrm{c}$ & $0.047 \mathrm{a}$ & $0.059 \mathrm{~B}$ \\
\hline Mean & $0.062 \mathrm{C}$ & $0.059 \mathrm{~B}$ & $0.061 \mathrm{BC}$ & $0.051 \mathrm{~A}$ & \\
\hline
\end{tabular}

Table 3

Values of linear correlation coefficients between Se content in nutrient medium $\left(\mathrm{Se}^{1}\right)$ and foliar Se spraying $\left(\mathrm{Se}^{2}\right)$ and chemical composition/yield of plants (significance level: ${ }^{*}-0.05,{ }^{* *} \leq 0.01$ )

\begin{tabular}{|c|c|c|c|c|c|c|c|c|c|c|c|c|c|c|}
\hline & \multirow{2}{*}{$S e^{l}$} & \multirow{2}{*}{$S e^{2}$} & \multicolumn{11}{|c|}{ Concentration in leaves } & \multirow{2}{*}{ Yield } \\
\hline & & & $N$ & $P$ & $K$ & $\mathrm{Ca}$ & $M g$ & $F e$ & $M n$ & $Z n$ & $C u$ & $\mathrm{Na}$ & $\mathrm{Se}$ & \\
\hline$S e^{I}$ & 1.00 & - & & & & & & & & & & & & \\
\hline$S e^{2}$ & - & 1.00 & & & & & & & & & & & & \\
\hline$N$ & -0.05 & 0.21 & 1.00 & & & & & & & & & & & \\
\hline$P$ & $-0.39^{*}$ & -0.01 & 0.06 & 1.00 & & & & & & & & & & \\
\hline$K$ & $-0.78^{* *}$ & 0.13 & 0.12 & -0.03 & 1.00 & & & & & & & & & \\
\hline $\mathrm{Ca}$ & $-0.45^{*}$ & $-0.77^{* *}$ & 0.14 & 0.12 & 0.40 & 1.00 & & & & & & & & \\
\hline$M g$ & 0.03 & $-0.43^{*}$ & 0.17 & -0.09 & 0.23 & $0.62^{* *}$ & 1.00 & & & & & & & \\
\hline $\mathrm{Fe}$ & 0.07 & -0.28 & 0.25 & -0.17 & 0.11 & 0.38 & $0.77^{* *}$ & 1.00 & & & & & & \\
\hline$M n$ & $-0.59^{* *}$ & 0.14 & 0.21 & 0.04 & $0.83^{* *}$ & 0.38 & $0.57^{* *}$ & 0.49 & 1.00 & & & & & \\
\hline$Z n$ & $-0.78^{* *}$ & 0.26 & -0.19 & $0.42^{*}$ & $0.70^{* *}$ & 0.18 & -0.03 & -0.20 & $0.61^{* *}$ & 1.00 & & & & \\
\hline$C u$ & 0.03 & -0.01 & 0.25 & 0.22 & 0.22 & 0.32 & $0.81^{* *}$ & $0.55^{\text {** }}$ & $0.61^{* *}$ & 0.24 & 1.00 & & & \\
\hline $\mathrm{Na}$ & $-0.59^{* *}$ & 0.18 & -0.34 & -0.14 & $0.66^{\text {** }}$ & 0.05 & 0.10 & 0.28 & $0.64^{* * *}$ & $0.54^{* *}$ & -0.02 & 1.00 & & \\
\hline $\mathrm{Se}$ & $0.59^{* *}$ & 0.10 & -0.26 & $-0.82^{* *}$ & -0.11 & -0.36 & 0.12 & 0.23 & -0.01 & -0.41 & -0.03 & 0.13 & 1.00 & \\
\hline Yield & $0.49^{* *}$ & $-0.49^{* *}$ & -0.28 & -0.12 & $-0.61^{* * *}$ & 0.10 & -0.13 & -0.23 & $-0.72^{* * *}$ & -0.42 & -0.26 & $-0.57^{* * t}$ & 0.01 & 1.00 \\
\hline
\end{tabular}

Increasing intensity of Se treatment generally decreased the quantitative relations between $\mathrm{Se}$ and metallic microelement $(\mathrm{Fe}, \mathrm{Mn}, \mathrm{Zn}, \mathrm{Cu}$ ) in leaves (Table 4). Wherein the average greatest changes in relative quantification was determined for $\mathrm{Zn}(-37.66 \%)$ and 
then for: $\mathrm{Mn}(-34.04 \%), \mathrm{Fe}(-17.55 \%)$ and $\mathrm{Cu}(-16.66 \%)$. In combination characterized by the worst yielding the $\mathrm{Mn}$ :Se ratio was 258.60:1 while in case of the best yielding the quantitative relations of $\mathrm{Fe}: \mathrm{Se}$ was the narrower and equal 139.59:1.

From the human health it is important to balance the diet in terms of both the macro- and micronutrients and functional elements. Both $\mathrm{Mn}$ and Se are necessary to human. Some soils around the world have insufficient Se contents, which makes it impossible for plants to accumulate this element [32]. For example, areas around the Baltic Sea are known as Se-deficient [33]. Also some soils in other parts of the EU show the same problem $[30,34,35]$. Deficits of Se content in the soil was the reason to undertake research on bio-fortification of vegetables with this element.

In many previous studies a positive increase in the Se status was found in plant tissues, caused by the application of different Se forms. Both the application of Se via the root-zone (in nutrient medium) and in foliar spraying significantly increased concentration of Se in lettuce leaves and roots [28]. Similarly as in the described study it was found that an Se addition (in concentration of 0.5 and $1.0 \mathrm{mg} \mathrm{Se} \mathrm{dm}^{-3}$ to the nutrient solution) resulted in an increase in the Se concentration in leaves, which had a positive impact on plant yielding [36]. Increasing Se nutrition has an effect on the concentration of that element in plants [26, 37, 38]. Se may also have an influence on $\mathrm{N}$ and $\mathrm{S}$ metabolic pathways (secondary metabolites production) what could be a beneficial aspects for health of consumers [27].

Table 4

The quantitative relations between metallic microelements and Se in lettuce leaves

\begin{tabular}{|c|c|c|c|c|c|}
\hline \multirow{2}{*}{ Plant spraying } & \multicolumn{5}{|c|}{ Se level in nutrient solution } \\
\cline { 2 - 6 } & Control & $\mathbf{0 . 7 7}$ & $\mathbf{1 . 0 5}$ & $\mathbf{1 . 3 3}$ & Mean \\
\hline \multicolumn{7}{|c|}{ Fe:Se } \\
\hline Distilled water & 44.80 & 37.38 & 52.70 & 34.59 & 42.37 \\
\hline Se solution & 45.33 & 37.06 & 30.06 & 39.73 & 38.05 \\
\hline Mean & 45.07 & 37.22 & 41.38 & 37.16 & \\
\hline \multicolumn{7}{|c|}{ Mn:Se } \\
\hline Distilled water & 242.09 & 226.05 & 214.91 & 139.59 & 205.66 \\
\hline Se solution & 258.60 & 197.99 & 184.26 & 190.69 & 207.88 \\
\hline Mean & 250.35 & 212.02 & 199.59 & 165.14 & \\
\hline \multicolumn{7}{|c|}{ Zn:Se } \\
\hline Distilled water & 8.03 & 8.01 & 4.97 & 4.64 & 6.41 \\
\hline Se solution & 8.91 & 6.47 & 5.70 & 5.91 & 6.75 \\
\hline Mean & 8.47 & 7.24 & 5.34 & 5.28 & \\
\hline \multicolumn{7}{|c|}{ Cu:Se } \\
\hline Distilled water & 2.47 & 2.69 & 2.55 & 1.65 & 2.34 \\
\hline Se solution & 2.80 & 1.69 & 1.92 & 2.76 & 2.29 \\
\hline Mean & 2.64 & 2.19 & 2.24 & 2.20 & \\
\hline
\end{tabular}

It was found that Se nutrition significantly modified the chemical composition of plants with macro- and microelements. Previous studies reported a varied influence of Se on nutrient contents. Smolen et al. [28] reported that Se has no a significant effect on contents of macroelements in lettuce leaves. Meanwhile [38] it was stated that independently of concentration, supplementation of Se weakly modified the nutrient concentrations in seedlings. Smolen et al. [28] determined generally higher concentrations of $\mathrm{N}, \mathrm{K}, \mathrm{Zn}$; lower: $\mathrm{Ca}, \mathrm{Mg}, \mathrm{Fe}$ and $\mathrm{Mn}$ with simultaneous similar concentrations of $\mathrm{P}$ and 
$\mathrm{Cu}$ in Se bio-fortified lettuce leaves, but it may have been connected with a different variety of lettuce and a different chemical composition of nutrient solution used for fertigation.

$\mathrm{Se}$ is frequently involved in antagonistic processes with metals $(\mathrm{Cu}, \mathrm{Zn}$ and $\mathrm{Cd})$ in plants and it also inhibits absorption of heavy metals, e.g. $\mathrm{Cd}$ or $\mathrm{Pb}[39,40]$. The novelty of our studies was not only connected with bio-fortification of lettuce with Se, but also a significant reduction of heavy metal contents, including $\mathrm{Mn}$, with an important improvement of plant yield. The Mn concentration in lettuce leaves in the case of plants grown with the standard cultivation $\left(0.5 \mathrm{mg} \mathrm{Mn} \mathrm{dm}^{-3}\right)$ is $328.4 \mathrm{mg} \mathrm{kg}^{-1} \mathrm{DM}$ [7]. With an increase to an excessive level $\left(19.2 \mathrm{mg} \mathrm{Mn} \mathrm{dm}^{-3}\right)$ the content of $\mathrm{Mn}$ in leaves increased about 1.5 times. For tomato grown in rockwool an increase in Mn level in nutrient solution from optimal to the excessive/toxic range caused an approx. 10-fold increase in Mn content [8]. In our studies it was found that by additional Se nutrition it is possible to reduce the content of $\mathrm{Mn}$ in lettuce leaves by about $36 \%$. Also Si application in nutrient solution (in the form of orthosilic acid) may reduce Mn content in tomato fruits by about $10 \%$ [41]. In the case of lettuce the application of the same form of Si did not influence the content of Mn in leaves [42].

Se generates some barriers for heavy metal transfer from the root zone to the aboveground plant parts - it was determined the strongest inhibition (84.9\%) in the case of $\mathrm{Pb}$ [20]. In earliest studies conducted on lettuce and Chinese cabbage it was found that $\mathrm{Se}$ can react the negative effects of $\mathrm{Pb}$ and $\mathrm{Cd}$, which results in a lower accumulation of these heavy metals in plants [43]. Simultaneously it was found a decreasing content of Mn in roots and in flag leaves of wheat (Triticum aestivum L. cv. Manu) under higher doses of Se $(15 \mu \mathrm{m})$ compared with a lower application rate $(5 \mu \mathrm{m} \mathrm{Se})[38]$. The protective role of Se in heavy metal stress, such as changes in root growth, viability, Reactive Oxygen Species production and antioxidant activity, is not unambiguous and depends mainly on Se concentration [24]. Se alleviated the Al-oxidative stress in ryegrass roots by the enhancement of spontaneous dismutation of superoxide radicals and the subsequent activation of peroxidase enzyme [21]. Others [44] suggested that Se is an antioxidant or it activates protective mechanisms, which alleviate oxidative stress in the chloroplasts. The spontaneous disproportion of superoxide to $\mathrm{H}_{2} \mathrm{O}_{2}$ may explain the slightly improved tolerance of photosynthesis [45].

A positive influence of Se application on lettuce yield was observed. It was reported that both quantitative and qualitative yield of plants was dose-dependent (concentration-dependent) on Se levels [37]. The optimal Se range of treatment is very narrow and excessive nutrition can produce oxidative stress and cause damage to plants $[46,47]$. Low concentration Se improves cell viability, whereas at high concentrations it was pro-oxidant and enhances lipid peroxidation and cell membrane injury [24]. Se fertilization increases chlorophyll ( $a, b$ and total contents) in onion leaves [48]. Se (in the forms of sodium selenate and sodium selenite) has two opposing effects on lettuce plant metabolism: at low doses it acts as an antioxidant and enhances plant growth, whereas at higher levels it reduces yields [26]. Selenium toxicity in high doses was also confirmed by other authors $[49,50]$.

\section{Conclusion}

Se nutrition significantly affected plant chemical composition - it decreased the Mn concentration (the lowest for Se-III with distilled water spraying), with a simultaneous 
increase of Se concentration (the highest was determined for Se-II with Se foliar treatment) and changes in concentrations of other nutrients in leaves. It was found that the most intensive Se nutrition (at Se-III), with simultaneous distilled water spraying, significantly improved plant yield. A statistically significant negative linear correlation was found between Se content in the nutrient medium and most of macroelements (except $\mathrm{N}$ ) $\mathrm{Na}, \mathrm{Mn}$ and $\mathrm{Zn}$ concentrations in leaves, while in the case of Se concentration in leaves and plant yield the correlation was significant and positive. In the case of Se spraying significant negative linear correlation coefficients were found only for $\mathrm{Ca}$ and $\mathrm{Mg}$ in edible parts of lettuce, as well as yield. Concluding it may be stated that additional Se nutrition via nutrient solution directly to root zone may increase food safety by reducing Mn concentration in their edible parts with a simultaneous improvement of yield potential.

\section{References}

[1] Dietary references intakes for vitamin A, vitamin K, arsenic, boron, chromium, copper, iodine, iron, manganese, molybdenum, nickel, silicon, vanadium and zinc. Website (December 2017) www.nap.edu/books/0309072794/html.

[2] Dobson AW, Erikson KM, Aschner M. Manganese neurotoxicity. Ann NY Acad Sci. 2004;1012:115-128. http://libres.uncg.edu/ir/uncg/f/K_Erikson_ManganeseNeurotoxicity_2004.pdf.

[3] Socha AL, Guerinot ML. Mn-euvering manganese: the role of transporter gene family members in manganese uptake and mobilization in plants. Front Plant Sci. 2014;5:106. DOI: $10.3389 / \overline{f p l s .20} \overline{14.00106 .}$

[4] Ferreira Santos E, Kondo Santini JM, Pereira Paixão A, Furlani Júnior E, Lavres J, Campos M, et al. Physiological highlights of manganese toxicity symptoms in soybean plants: Mn toxicity responses. Plant Physiol Biochem. 2017;113:6-19. DOI: 10.1016/j.plaphy.2017.01.022.

[5] Homoncik SC, MacDonald AM, Heal KV, Dochartaigh BEO, Ngwenya BT. Manganese concentrations in Scottish groundwater. Sci Total Environ. 2010;408(12):2467-2473. DOI: 10.1016/j.scitotenv.2010.02.017.

[6] Breś W, Kleiber T, Trelka T. Quality of water used for drip irrigation and fertigation of horticultural plants. Folia Hort. 2010;22(2):67-74. http://www.ptno.ogr.ar.krakow.pl/Wydawn/FoliaHorticulturae/Spisy/ FH2010/PDF22022010/fh2202p10.pdf.

[7] Kleiber T. Effect of manganese nutrition on content of nutrient and yield of lettuce (Lactuca sativa L.) in hydroponic. Ecol Chem Eng S. 2014;21(3):529-537. DOI: 10.2478/eces-2014-0039.

[8] Kleiber T. Changes of nutrient contents in tomato fruits under the influence of increasing intensity of manganese nutrition. Ecol Chem Eng S. 2014.;21(2):297-307. DOI: $10.2478 / \mathrm{eces}-201 \overline{4}-0023$.

[9] Commission Regulation (EU) No 420/2011 of 29 April 2011 amending Regulation (EC) No 1881/2006 setting maximum levels for certain contaminants in foodstuffs. https://www.fsai.ie/uploadedFiles/ Reg420_2011.pdf.

[10] Jolly YN, Islam A, Akbar S. Transfer of metals from soil to vegetables and possible health risk assessment. SpringerPlus. 2013;2(1):385. DOI: 10.1186/2193-1801-2-385.

[11] Zhou H, Yang W-T, Zhou X, et al. Accumulation of heavy metals in vegetable species planted in contaminated soils and the health risk assessment. Int J Environ Res Public Health. 2016;13(3):289. DOI: 10.3390/ijerph13030289.

[12] Thomsen HS, Svendsen O, Klastrup S. Increased manganese concentration in the liver after oral intake. Academic Radiol. 2004;11,1:38-44; DOI: 10.1016/S1076-6332(03)00571-3.

[13] Neal AP, Guilarte TT. Mechanisms of heavy metal neurotoxicity: Lead and manganese. J Drug Metab Toxicol. 2012;S5 002:1-13. DOI: 10.4172/2157-7609.S5-00.

[14] O'Neal SL, Zheng W. Manganese toxicity upon overexposure: A decade in review. Curr Environ Health Reports. 2015;2(3):315-328. DOI: $10.1007 / \mathrm{s} 40572-015-0056-\mathrm{X}$.

[15] Liang Y, Wanchun S, Yong-Guan Zhu, Christie P. Mechanisms of silicon-mediated alleviation of abiotic stresses in higher plants: a review. Environ Pollut. 2007;147,2:422-428. DOI: $10.1016 / \mathrm{j}$.envpol.2006.06.008.

[16] Maksimović DJ, Bogdanović J, Maksimović V, Nikolic M. Silicon modulates the metabolism and utilization of phenolic compounds in cucumber (Cucumis sativus L.) grown at excess manganese. J Plant Nutr Soil Sci. 2007;170:739-744. DOI: 10.1002/jpln.200700101.

[17] Liu R, Jia T, Cui Y, Lin H, Li S. The protective effect of selenium on the chicken pancreas against cadmium toxicity via alleviating oxidative stress and autophagy. Biol Trace Elem Res. 2017;1-7. DOI: 10.1007/s12011-017-1186-9. 
[18] Ikemoto T, Kunito T, Tanaka H, Baba N, Miyazaki N, Tanabe S. Detoxification mechanism of heavy metals in marine mammals and seabirds: interaction of selenium with mercury, silver, copper, zinc and cadmium in liver. Arch Environ Con Toxicol. 2004;47:402-413. DOI: 10.1007/s00244-004-3188-9.

[19] Soudani N, Sefi M, Ben Amara I, Boudawara T, Zeghal N. Protective effects of selenium (Se) on chromium (VI) induced nephrotoxicity in adult rats. Ecotox Environ Safe. 2010;73:671-678. DOI: 10.1016/j.ecoenv.2009.10.002.

[20] Fargašová A, Pastierová J, Svetková K. Effect of Se-metal pair combinations $(\mathrm{Cd}, \mathrm{Zn}, \mathrm{Cu}, \mathrm{Pb}) \mathrm{on}$ photosynthetic pigments production and metal accumulation in Sinapis alba L. seedlings. Plant Soil Environ. 2006;52:8-15. http://www.agriculturejournals.cz/publicFiles/50511.pdf.

[21] Cartes P, Jara AA, Pinilla L, Rosas A, Mora ML. Selenium improves the antioxidant ability against aluminium-induced oxidative stress in ryegrass roots. Annals Appl Biol. 2010:1 $\overline{56(2): 297-307 .}$ DOI: $10.1111 / \mathrm{j} .1744-\overline{7348.2010} . \overline{00387} . x$.

[22] Barrientos EY, Flores CR, Wrobel K, Wrobel K.. Impact of cadmium and selenium exposure on trace elements, fatty acids and oxidative stress in Lepidium sativum. J Mex Chem Soc. 2012;56(1):3-9. http://www.scielo.org.mx/scielo.php?script=sci_arttext\&pid=S1870-249X2012000100002.

[23] Kumar M, Bijo AJ, Baghel RS, Reddy CRK, Jha B. Selenium and spermine alleviates cadmium induced toxicity in the red seaweed Gracilaria dura by regulating antioxidant system and DNA methylation. Plant Physiol Biochem. 2012;51:129-138. DOI: 10.1016/j.plaphy.2011.10.016.

[24] Mroczek-Zdyrska M, Wójcik M. The influence of selenium on root growth and oxidative stress induced by lead in Vicia faba L. minor plants. Biol Trace Elem Res. 2012;147:320-328, DOI: 10.1007/s12011-011-9292-6.

[25] Feng R, Wei Ch, Tu S. The roles of selenium in protecting plants against abiotic stresses. Environ Exp Botany. 2013;87:58-68. DOI: $10.1016 /$ j.envexpbot.2012.09.002.

[26] Ramos SJ, Faquin V, Guilherme LRG, Castro EM, Ávila FW, Carvalho GS, et al. Selenium biofortification and antioxidant activity in lettuce plants fed with selenate and selenite. Plant Soil Environ. 2010; $\overline{56(12): 584-588 . \text { DOI: }} \overline{10.17221 / 1} 13 / 2010-\overline{\text { PSE. }}$

[27] Malagoli M, Schiavon M, dall'Acqua S, Pilon-Smits EAH. Effects of selenium biofortification on crop nutritional quality. Frontiers Plant Sci. 2015;6:280. DOI: 10.3389/fpls.2015.00280.

[28] Smoleń S, Kowalska I, Sady W. Assessment of biofortification with iodine and selenium of lettuce cultivated in the NFT hydroponic system. Scientia Horticulturae. 2014;166:9-16. DOI: 10.1016/j.scienta.2013.11.011.

[29] Rayman MP. The importance of selenium to human health. Lancet. 2000;365:233-241. https://pdfs.semanticscholar.org/73b1/4abf5792b38e2b98ef2cf74c1541e9f78869.pdf.

[30] Fairweather-Tait SJ, Bao Y, Broadley MR, Collings R, Ford D, Hesketh JE, et al. Selenium in human health and disease. Antioxid. Redox Signal. 2011;14:1337-1383. DOI: 10.1089/ars.2010.3275.

[31] Kalembasa S, Jaremko D, Adamiak EA. Wpływ sposobu mineralizacji substancji organicznej na zawartość makro- i mikroelementów w makuchu rzepakowym. (Impact of organic matter mineralisation method on the content of macro- and microelements of rapeseed cake). Acta Agrophys. 2011;18(1):77-85. http://agro.icm.edu.p1/agro/element/bwmeta1.element.agro-53b5f0ea-bbe8-4dc3-b41a-bb1ea51789d6.

[32] White PJ, Broadley M.R. Biofortification of crops with seven mineral elements often lacking in human diets - iron, zinc, copper, calcium, magnesium, selenium and iodine. New Phytol. 2009;182:49-84. DOI: 10.1111/j.1469-8137.2008.02738.x.

[33] Reimann C, Siewers U, Tarvainen T, Bityukova L, Eriksson J, Gilucis A, et al. Agricultural Soils in Northern Europe: A Geochemical Atlas. Stuttgart: Schweizerbart'sche Verlagsbuchhandlung; 2003, Germany, 280. ISBN 978-3-510-95906-8.

[34] Romero CD, Blanco FL, Sánchez PH, Rodríguez E, Majem LS. Serum selenium concentration in a representative sample of the Canarian population. Sci Total Environ. 2001;269:65-73. DOI: 10.1016/S0048-9697(00)00815-9.

[35] Broadley MR, White PJ, Bryson RJ, Meacham MC, Bowen HC, Johnson SE, et al. Biofortification of UK food crops with selenium. Proc Nutr Soc. 2006;65:169-181. https://pdfs.semanticscholar.org/1ae0/ 140adb4b906654b5dfb7ca7b3bae091bc2fe.pdf.

[36] Malorgio F, Diaz KE, Ferrante A, Mensuali-Sodid A, Pezzarossae B. Effects of selenium addition on minimally processed leafy vegetables grown in a floating system. J Sci Food A gric. $\overline{2009 ; 89} \overline{2243-2251 .}$ DOI: $10.1002 /$ jsfa.3714.

[37] Põldma P, Moor U, Tõnutare T, Herodes K, Rebane R. Selenium treatment under field conditions affects mineral nutrition, yield and antioxidant properties of bulb onion (Allium cepa L.). Acta Sci Pol Hortorum Cultus. 2013:12(6):167-181. https://www.etis.ee:2345/File/DownloadPublic/77d7c4b8-d06b-4492-81a1bf01a309616d?name=Fail_Poldma_etal_ActaPolonorum_2013.pdf\&type=application\%2Fpdf. 
[38] Tobiasz A, Walas S, Filek M, Mrowiec H, Samsel K, Sieprawska A, et al. Effect of selenium on distribution of macro- and micro-elements to different tissues during wheat ontogeny. Biol Plant. 2014;58(2):370-374. DOI: $10.1007 / \mathrm{s} 10535-014-0407-8$.

[39] Wu Z, Yin X, Bañuelos GS, Lin Q, Liu Y, Li M, et al. Indications of selenium protection against cadmium and lead toxicity in oilseed rape (Brassica napus L.). Frontiers Plant Sci. 2016;7:1875. DOI: 10.3389/fpls.2016.01875.

[40] Kumar M, Bijo AJ, Baghel RS, Reddy CRK, Jha B. Selenium and spermine alleviates cadmium induced toxicity in the red seaweed Gracilaria dura by regulating antioxidant system and DNA methylation. Plant Physiol Biochem. 2012;51:129-138. DOI: 10.1016/j.plaphy.2011.10.016.

[41] Kleiber T, Calomme M, Borowiak K. The effect of choline-stabilized orthosilicic acid on microelements and silicon concentration, photosynthesis activity and yield of tomato grown under Mn stress. Plant Physiol Biochem. 2015;96:180-188. DOI: 10.1016/j.plaphy.2015.07.033.

[42] Kleiber T. The effect of silicon application under Mn excessive nutrition on yielding of hydroponically grown lettuce (Lactuca sativa L.). ABiD. 2014;3:7-14. DOI: 10.5601/jelem.2015.20.1.806.

[43] He PP, Lv XZ, Wang GY. Effects of Se and $\mathrm{Zn}$ supplementation on the antagonism against $\underline{\mathrm{Pb}}$ and $\underline{\mathrm{Cd}}$ in vegetables. Environ Int. 2004;30:167-172. DOI: 10.1016/S0160-4120(03)00167-3.

[44] Seppänen M, Turakainen M, Hartikainen H. Selenium effects on oxidative stress in potato. Plant Sci. 2003;165:311-319. DOI: 10.1016/S0168-9452(03)00085-2.

[45] Xue T, Hartikainen H, Piironen V. Antioxidative and growth promoting effect of selenium in senescing lettuce. Plant Soil. 2001;237:55-61. DOI: 10.1023/A 1013369804867.

[46] Hartikainen H, Xue TL, Piironen, V. Selenium as an anti-oxidant and prooxidant in ryegrass. Plant Soil. 2000;225:193-200. DOI: 10.1023/A:1026512921026.

[47] Mora M, Pinilla L, Rosas A, Cartes P. Selenium uptake and its influence on the antioxidative system of white clover as affected by lime and phosphorus fertilization. Plant Soil. 2008;303:139-149. DOI: 10.1007/s11104-007-9494-z.

[48] Moldovan C, Ianculov I, Hădărugă NG, Dumbravă D, Crăiniceanu E, Drugă M, et al. Influence of chlorophyll content from onion (Allium cepa) after selenium and zinc adding. J Agroaliment Proc Technol. 2009;15:437-440. http://www.journal-of-agroalimentary.ro/admin/articole/55864L81_Moldovan_Camelia_ 437-440.pdf.

[49] Grant K, Carey NM, Mendoza M, Schulze J, Pilon M, Pilon-Smits EAH, et al. Adenosine 5-phosphosulfate reductase (APR2) mutation in Arabidopsis implicates glutathione deficiency in selenate toxicity. Biochem J. 2011;438:325-335. DOI: 10.1042/BJ20110025.

[50] Gupta M, Gupta S. An overview of selenium uptake, metabolism, and toxicity in plants. Frontiers Plant Sci. 2016;7:2074. DOI: 10.3389/fpls.2016.02074. 